\title{
Expression, purification of herpes simplex virus type 1 US11 Protein, and production of US11 polyclonal antibody
}

\author{
Yizhong Huang, Wuyunerdeni and Shanglong Yao*
}

\begin{abstract}
Background: The US11 protein of herpes simplex virus type 1 (HSV-1) is a small, highly basic phosphoprotein expressed at late times during infection. To date, the function of US11 protein in cell culture and animal models is poorly understood. To further investigate the function of the US11 protein, this study was undertaken to express the US11 protein and raise a polyclonal antibody.

Results: The US11 gene was cloned into the prokaryotic expression vector pET-32a (+) to express His-tagged US11 protein in Escherichia coli. After purification by nickel affinity chromatography and refolding, the recombinant protein was used to raise the anti-US11 polyclonal antibody. Western blot analysis demonstrated that the US11 protein was specifically recognized by the polyclonal antibody, and immunofluorescent assay also showed that the antibody was able to probe the US11 protein in the cells infected with HSV-1.
\end{abstract}

Conclusions: In the present study, we obtained a high-level expression of the recombinant US11 protein as well as high titers of rabbit polyclonal antibody specially against US11 protein in HSV-1 infected cells. This special polyclonal antibody provides a good tool for further studying structural and functional characterization of HSV-1 US11 protein.

Keywords: Herpes simplex virus type 1 (HSV-1), US11 protein, Protein expression, Polyclonal antibody, Immunofluorescent assay

\section{Background}

Herpes simplex virus type 1 (HSV-1) is a large DNA virus that latently infects neurons and periodically reinitiates productive growth at epithelial sites, causing blisters, or in the central nervous system, resulting in encephalitis. During productive infection, the $152-\mathrm{kb}$ double-stranded HSV-1 genome is rapidly translocated to the nucleus where at least 80 viral genes are transcribed by the host cell RNA polymerase II (Pol II) [1]. Expression of the viral genes occurs in a coordinately activated cascade fashion that consists of the sequential expression of immediate-early (IE), early (E), and late (L) genes [2]. The US11 protein expresses at late times during HSV-1 infection and is one of the late genes of HSV-1 [3].

\footnotetext{
* Correspondence: yao_shanglong@yahoo.com.cn Department of Anesthesiology, Union Hospital, Tongji Medical College, Huazhong University of Science and Technology, 1277 Jiefang Avenue, Wuhan, 430022, China
}

(c) 2011 Huang et al; licensee BioMed Central Ltd. This is an Open Access article distributed under the terms of the Creative Commons Attribution License (http://creativecommons.org/licenses/by/2.0), which permits unrestricted use, distribution, and reproduction in any medium, provided the original work is properly cited. The US11 protein is a $21 \mathrm{kDa}$, highly basic phosphoproscriptional regulator of gene expression [5-7]. US11 is present in the nucleus, particularly concentrated in the nucleolus, and the cytoplasm $[8,9]$ and is present in the virion as a component of the tegument (approximately 600 to 1,000 molecules per virion). Furthermore, US11 interacts with several different cellular proteins such as human ubiquitous kinesin heavy chain (uKHC) [10], homeodomain interacting protein kinase 2 (HIPK2) [11], double-stranded RNA-dependent protein kinase (PKR) and a dsRNA-independent protein activator of PKR (PACT) [12,13]. US11 has been reported as a potent inhibitor of PKR activation through binding to dsRNA [14] or through direct interaction with PKR in the context of viral infection [12] and therefore could interfere with the PKR mediated host cell responses. Finally, US11 has been recently shown to also counteract the activity of the 2'-5' oligoadenylate synthetase 
(OAS), a cellular protein critical for host cell defense [15]. Therefore, it is clear that US11 is a multifunctional protein involved in HSV-1 infection.

In the present study, the US11 gene was cloned into pET-32a(+) to yield pET-32a-US11. The His-tagged US11 protein was then expressed in E. coli BL21 (DE3) cells and purified by a nickel-nitrilotriacetic acid $\left(\mathrm{Ni}^{2}\right.$ ${ }^{+}$-NTA) affinity resin under denaturing conditions. Subsequently, a polyclonal antibody was raised against the purified His-tagged US11 protein in rabbits. Finally, the reactivity and specificity of the polyclonal antibody were characterized by Western blot and immunofluorescent assays.

\section{Results}

Construction of the US11 prokaryotic expression plasmid The full-length US11 gene, which is composed of 459 bp (base pairs) and predicted to encode a protein of 152 amino acids, was amplified successfully from the HSV-1 (strain F) genome (Figure 1, lane 1). The PCR product was digested with EcoRI and SalI and inserted into pET-32a (+) digested with the same enzymes to yield the recombinant expression plasmid pET-32a-US11. Then, the recombinant plasmid was verified by colony PCR (Figure 1, lane 2 ) and restriction enzymes digestion (Figure 1, lane 3). The sequencing result also showed that there was no mutation of amino acid sequences (data not shown).

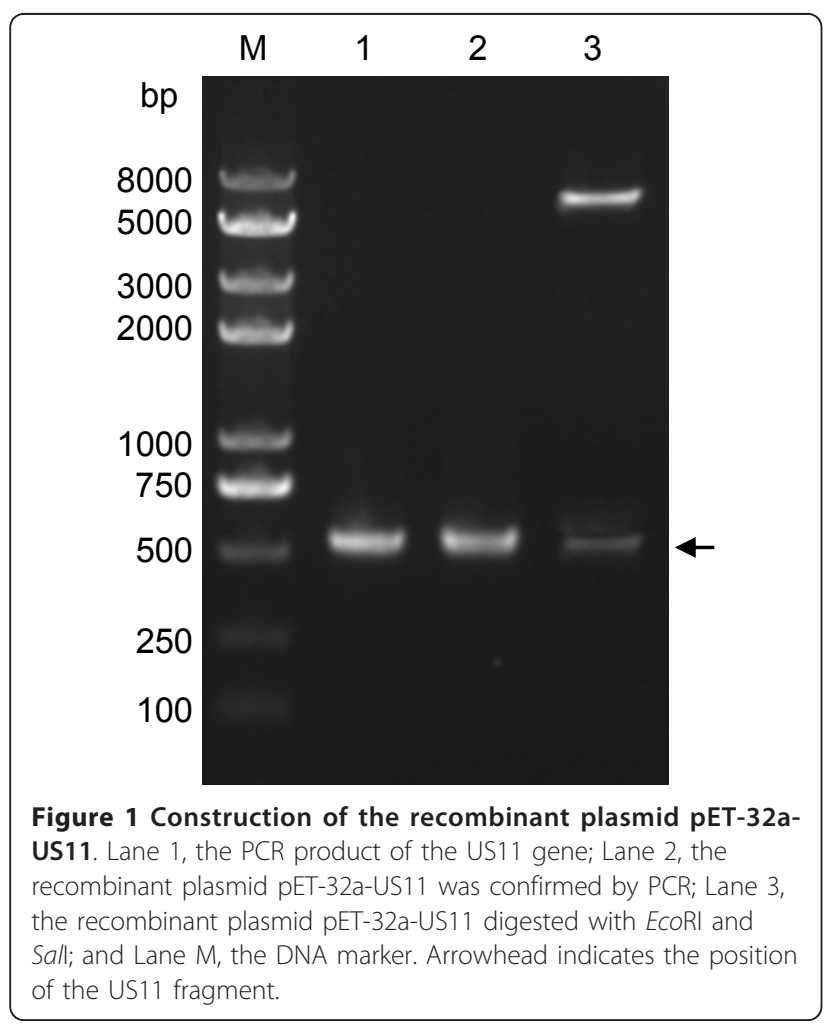

\section{Expression of the His-tagged US11 protein}

After induction with $1.0 \mathrm{mM}$ IPTG at $37^{\circ} \mathrm{C}$ for $4 \mathrm{~h}$, E. coli BL21 (DE3) harboring pET-32a-US11 exhibited a high level of expression (Figure 2A, lane 3). A distinct band of approximately $40 \mathrm{kDa}$, corresponding to the expected molecular weight of the His-tagged US11 protein, was found only after induction (Figure 2A, lanes 27 ), whereas there was no expression of the US11 protein in BL21(DE3) harboring pET32a-US11 without IPTG induction (Figure 2A, lane 1).

Additionally, according to the SDS-PAGE analysis of the soluble fraction and cell debris pellet (Figure 2A, lanes 8 and 9), the majority of the induced protein was found in the cell debris pellets (Figure 2A, lane 9), suggesting that

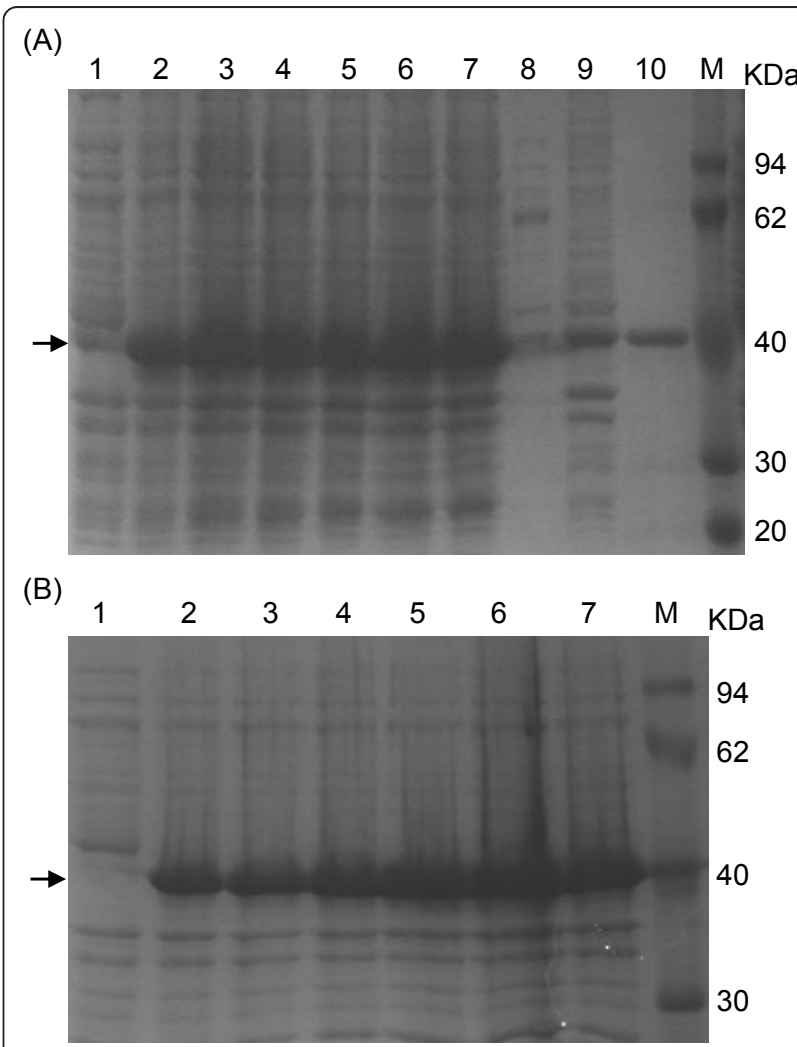

Figure 2 Expression analysis and optimization of the expression for the His-tagged US11 protein. (A) Analysis of expressed His-tagged US11 protein and optimization of the IPTG concentration and induction temperature. Lane 1, total protein from BL21 (DE3) with pET32a-US11 before induction; Lanes 2-5, total protein from pET32a-US11 transformed BL21 (DE3) after induction with the concentrations of IPTG: $0.5,1,1.5$ and $2 \mathrm{mM}$, respectively. Lanes 6 and 7, total protein from pET-32a-US11 transformed BL21 (DE3) after induction at $30^{\circ} \mathrm{C}$ and $37^{\circ} \mathrm{C}$, respectively. Lane 8 , soluble fractions; Lane 9, insoluble fractions; Lane 10, the purified US11 protein after dialysis; Lane $M$, the protein maker. (B) Optimization of the induction duration. Lanes 1-7, total protein from pET32a-US11 transformed BL21 (DE3) after induction with IPTG (1 mM) for 0, 1, 2, $3,4,5$ and $6 \mathrm{~h}$, respectively, at $37^{\circ} \mathrm{C}$. Lane $\mathrm{M}$, the protein maker. Arrowheads indicate the position of the His-tagged US11 protein. 
the His-tagged US11 protein was insoluble in the form of inclusion bodies. Meanwhile, several expression parameters, including IPTG concentrations (Figure 2A, lanes 2-5), induction temperatures (Figure 2A, lanes 6 and 7) and induction times (Figure 2B), were tested to optimize the expression of the US11 protein as previously described [16]. As results, the recombinant protein was found to have the highest expression under the following condition, namely 1 mM IPTG (Figure 2A, lane 3) for $5 \mathrm{~h}$ (Figure 2B, lane 6) at $37^{\circ} \mathrm{C}$ (Figure 2A, lane 7).

\section{Purification of the His-tagged US11 protein}

The His-tagged US11 protein was purified as previously described [16]. The SDS-PAGE results verified the successful purification, because only one clear band with molecular weight about $40 \mathrm{kDa}$ was observed (Figure 2A, lane 10). After purification, the His-tagged US11 protein was quantified. The result showed that the concentration of the purified His-tagged US11 protein was $911.3 \mu \mathrm{g} / \mathrm{ml}$ (data not shown).

\section{Production and characterization of the polyclonal antibody against purified His-tagged US11 protein}

After three immunizations, the rabbit antiserum was collected as previously described [16]. Western blot results demonstrated that the anti-US11 polyclonal antibody reacted with one band with apparent molecular masses of $21 \mathrm{kDa}$ in Vero cells infected with HSV-1 (Figure 3, lane 5 ) at a dilution of 1:800. In contrast, no band was detected in mock infected Vero cells (Figure 3, lane 4). Moreover, the anti-US11 polyclonal antibody could recognize the band with apparent molecular weight of $40 \mathrm{kDa}$ in lysate of $E$. coli BL21 (DE3) transformed with the plasmid pET32a-US11 after induction by IPTG (Figure 3, lane 3) and the expected $23 \mathrm{kDa}$ band in lysate of HEK293T cells transfected with plasmid encoding US11-HA protein (Figure 3, lane 1), whereas no band was detected in lysate of E. coli BL21 (DE3) (Figure 3, lane 2).

Immunofluorescent assay revealed that anti-US11 polyclonal antibody identified the US11 protein expressed in the cells infected with HSV-1. The results demonstrated that the US11 protein localized in the cytoplasm and nucleolus of the infected cell (Figure 4C), which is consistent with previous reports $[9,17]$. In contrast, there was no staining in mock infected cells (Figure 4B) or HSV-1 infected cells detected with the preimmune serum (Figure $4 \mathrm{~A}$ ). These results suggested that the polyclonal antibody had good reactivity and specificity against the US11 protein in infected cells, which were consistent with previous studies involved [10-12,18].

\section{Discussion}

In general, recombinant proteins are the most common source of the diagnostic reagents and can be expressed in mammalian, insect and bacterial cells [19-21]. While each of these systems has its advantages [22], the bacterial expression system is one of the most universally used and has been employed widely due to multiple factors, including its relative inexpensive cost, ease of manipulation and rapid growth rate [23]. However, different codon usage pattern in $E$. coli can cause diminished the production of heterologous eukaryotic protein. Many $E$. coli strains, such as BL21 CodonPlus and Rosetta-2 derived from BL21, are optimized to enhance expression of gene sequences that contain codons used rarely by $E$. coli [24]. Because there are a few rare codons in the US11 gene, three different $E$. coli strains, including $E$. coli BL21 (DE3), BL21 CodonPlus and BL21 Rosetta

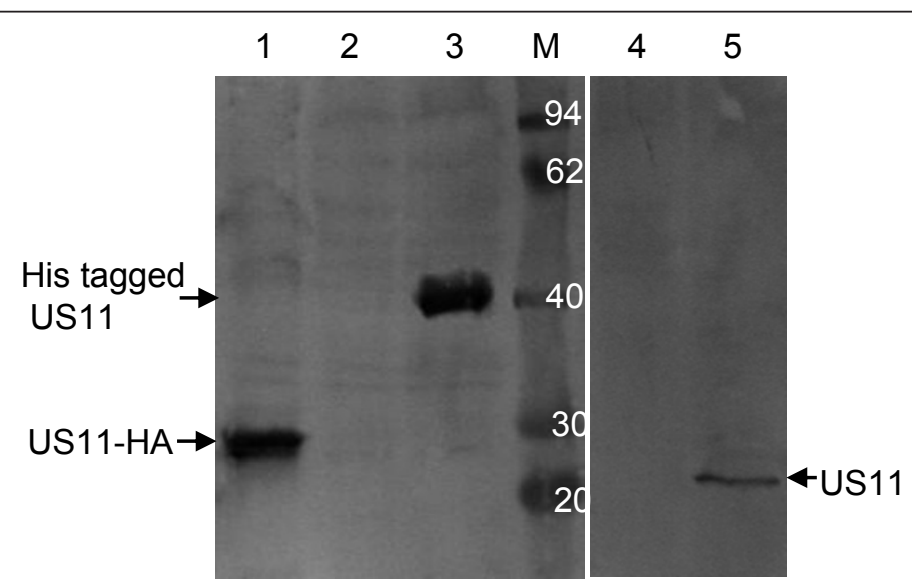

Figure 3 Western blot analysis of US11 with anti-US11 polyclonal antibody. Lane 1, the lysate of HEK293T cells transfected with plasmid encoding full-length US11-HA protein; Lane 2, total protein from E. coli BL21 (DE3); Lane 3, total protein from E. coli BL21 (DE3) harboring the plasmid pET-32a-US11 after induction by IPTG; Lane 4, the lysate of mock infected Vero cells; Lane 5, the lysate of Vero cells infected with HSV-1; Lane $\mathrm{M}$, the protein maker $(\mathrm{kDa})$. Arrowheads indicate the position of the US11 protein. 


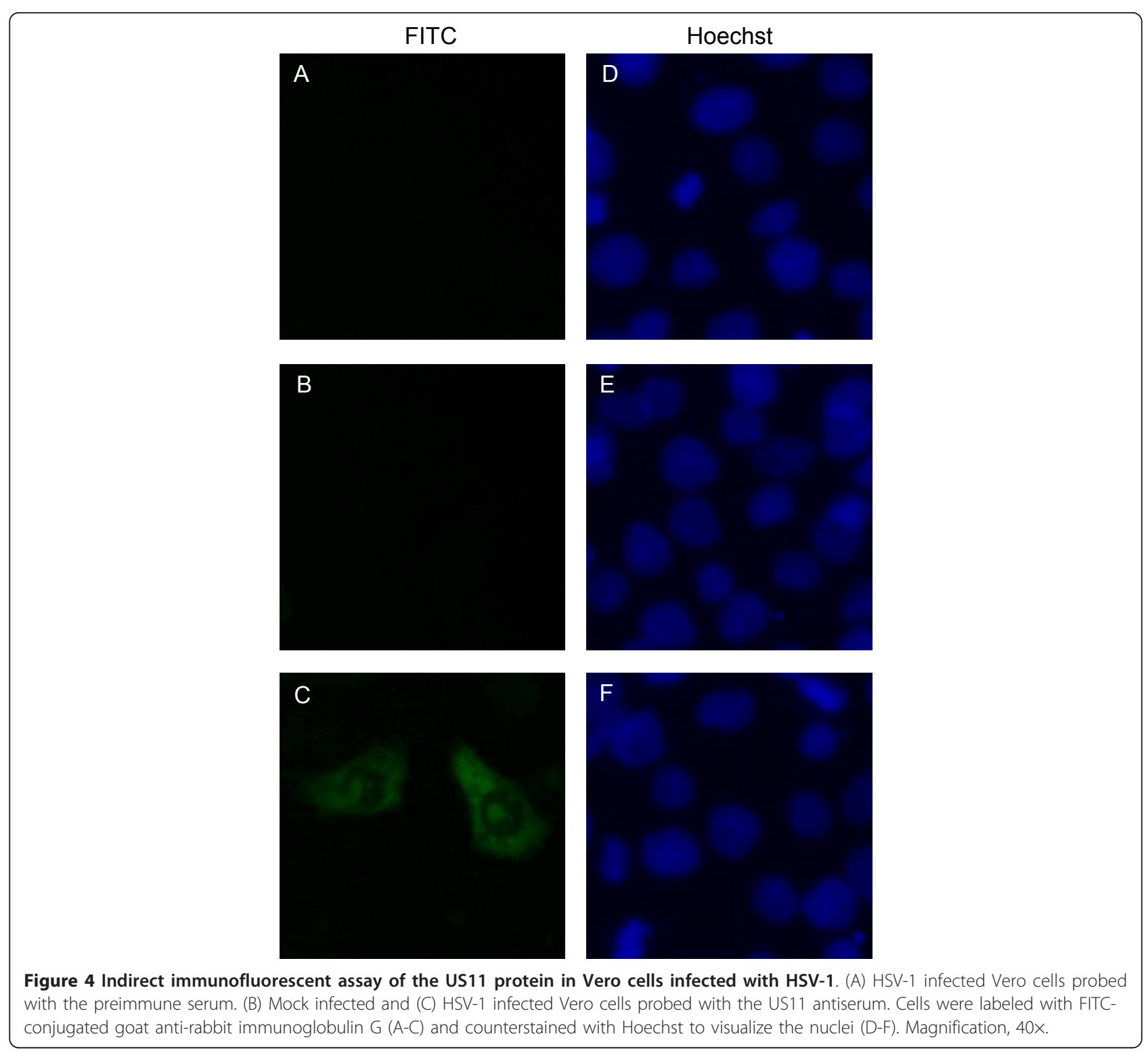

were used to optimize the expression of the fusion protein. As a result, the His-tagged US11 protein could be expressed in all of these three bacteria hosts, but with a slight better expression in E. coli BL21 (DE3) (data not shown). Additionally, different expression parameters were tested to optimize the expression of the US11 protein, demonstrating that the US11 protein gained the highest expression under the condition of $37^{\circ} \mathrm{C}$ (Figure $2 \mathrm{~A}$, lane 7) with $1 \mathrm{mM}$ IPTG (Figure 2A, lane 3 ) for $5 \mathrm{~h}$ (Figure 2B, lane 6).

It is very common that high level expression of recombinant proteins in $E$. coli result in the formation of insoluble and inactive aggregate known as inclusion bodies [25]. Although the proteins in the inclusion bodies are easy to purify and are protected from the intracellular protease, they are synthesized in the form of misfolding or partial folding polypeptides. Therefore, purified inclusion bodies must undergo the process of protein renaturation. In the present study, denaturation solution was removed by dilution or dialysis, which permitted renaturation of the His-tagged US11 proteins. However, the proteins purified from the inclusion bodies are not suitable for the researches that require the correct protein conformation.

The US11 protein is among the most-abundant viral proteins present in cells late in infection and is packaged in the tegument of the native virions [17]. In this study, anti-US11 polyclonal antibody reacted with one band with apparent molecular masses of $21 \mathrm{kDa}$ in Vero cells infected with HSV-1 for 24 h., which is consistent with 
previous reports used by monoclonal or polyclonal antibodies against US11 [4,10-12]. The specificity of our US11 polyclonal antibody was confirmed by both WB and IFA in transfected and infected cells, and it also worked well, which maybe special advantages of our antibody over those antibodies. The subcellular localization of a viral protein determines its function. It is reported that soon after HSV-1 infection, the US11 protein is found in the cytoplasm, either as heterogeneous oligomers or associated with ribosomes or both $[26,27]$. Later during infection, the US11 protein accumulates into nucleoli and is also found in RNP fibrils as well as in clusters of interchromatin granules. As expected, our results also demonstrate that the US11 protein localizes in the cytoplasm and nucleolus of the infected cell.

Early studies have demonstrated US11 is a multifunctional protein involved in posttranscriptional regulation of gene expression and in biological processes related to the survival of cells following environmental stress [11]. To further gain insight into the molecular mechanisms underlying the multiple functions of this protein, identification of cellular factors capable of interacting with the US11 protein is necessary. Therefore, the anti-US11 polyclonal antibody may serve as a useful tool for further study of US11 interaction partners by coimmunoprecipitation.

\section{Conclusions}

In the present study, we obtained a high-level expression of the recombinant US11 protein as well as high titers of rabbit polyclonal antibody against US11 protein specially. The anti-US11 serum was able to detect the US11 protein in HSV-1 infected cells and the US11 protein localized in the cytoplasm and nucleolus of the infected cell. This special polyclonal antibody provides a good tool for further studying structural and functional characterization of HSV-1 US11 protein.

\section{Materials and methods}

\section{Construction of the plasmid expressing the His-tagged US11 protein}

The US11 gene of HSV-1 (strain F) was amplified by PCR using KOD plus polymerase (Toyobo, Osaka, Japan) from the pYEbac102 [28] using the following primers: 5' CGGAATTCATGAGCCAGACCCAACC 3' and 5' ACGCGTCGACTACAGACCCGCGAGCCGT 3' as previously described. The purified PCR product was digested with EcoRI and SalI (Takara, Dalian, China), and inserted into pET-32a (+) (Novagen, Shanghai, China) to generate a recombinant plasmid pET-32a-US11.

\section{Expression of the His-tagged US11 protein}

E.coli BL21 (DE3) was transformed with pET-32a-US11 and the transformant was inoculated into LB medium containing $50 \mu \mathrm{g} / \mathrm{ml}$ ampicillin and grown for $12 \mathrm{~h}$ at $37^{\circ} \mathrm{C}$. The culture was transferred to fresh LB medium and grown at $37^{\circ} \mathrm{C}$ until the $\mathrm{OD}_{600}$ reached about 0.5 . Then the recombinant protein was induced by isopropyl- $\beta$-D-thiogalactopyranoside (IPTG) at a final concentration of $1 \mathrm{mM}$ for $4 \mathrm{~h}$. The total bacterial lysates were analyzed by SDS-PAGE [29].

To increase the yield, the expression of the His-tagged US11 protein was optimized as previously described [16] at different temperatures $\left(30^{\circ} \mathrm{C}\right.$ and $\left.37^{\circ} \mathrm{C}\right)$, different concentrations of IPTG $(0.5,1.0,1.5$ and $2.0 \mathrm{mM})$, and varying durations of induction $(0,1,2,3,4,5$ and $6 \mathrm{~h})$. Protein expression was assessed by SDS-PAGE.

\section{Analysis of the solubility of the His-tagged US11 protein}

The analysis was performed as previously described [16].

\section{Purification and renaturation of the His-tagged US11 protein}

The purification and renaturation of the His-tagged US11 protein were performed as previously described [16]. After analysis by $12 \%$ SDS-PAGE, the yield of the purified His-tagged US11 protein was quantified by Coomassie (Bradford) Protein Assay Kit (Pierce, Beijing, China) [30].

\section{Production of polyclonal antibody against the His-tagged US11 protein}

The immunizations were performed as previously described [16], except that the His-tagged US11 fusion protein was used in this study.

\section{Western blot}

Western blot was performed as previously described [16], except that the anti-US11 polyclonal antibody (1:800 dilution) was applied in this study.

\section{Indirect immunofluorescent assay}

Immunofluorescent assay was performed as previously described [16]. However, the Vero cells were infected with the HSV-1 at a MOI of 1 and fixed $20 \mathrm{~h}$ after infection. Additionally, the anti-US11 polyclonal antibody at a dilution of 1:800 was applied in this study.

\section{Acknowledgements \\ Dr. Yasushi Kawaguchi is gratefully acknowledged for the generous gifts pYEbac102.}

\section{Authors' contributions}

YH carried out most of the experiments and drafted the manuscript. W participated in construction of US11 plasmid. SY have critically revised the manuscript and the experimental design. All the authors read and approved the final manuscript.

Competing interests

The authors declare that they have no competing interests. 
Received: 10 September 2011 Accepted: 31 October 2011

Published: 31 October 2011

\section{References}

1. Roizman B, Knipe DM, Whitley RJ: Herpes simplex virus. Fields Virology. 5 edition. Philadelphia: Lippincott Williams \& Wilkins; 2007, 2501-2601.

2. McGeoch DJ, Dalrymple MA, Davison AJ, Dolan A, Frame MC, McNab D, Perry $L$, Scott JE, Taylor P: The complete DNA sequence of the long unique region in the genome of herpes simplex virus type 1. J Gen Virol 1988, 69(Pt 7):1531-1574.

3. Johnson PA, MacLean C, Marsden HS, Dalziel RG, Everett RD: The product of gene US11 of herpes simplex virus type 1 is expressed as a true late gene. J Gen Virol 1986, 67(Pt 5):871-883.

4. Schaerer-Uthurralt N, Erard M, Kindbeiter K, Madjar JJ, Diaz JJ: Distinct domains in herpes simplex virus type 1 US11 protein mediate posttranscriptional transactivation of human T-lymphotropic virus type I envelope glycoprotein gene expression and specific binding to the Rex responsive element. The Journal of general virology 1998, 79(Pt 7):1593-1602.

5. Attrill HL, Cumming SA, Clements JB, Graham SV: The herpes simplex virus type 1 US11 protein binds the coterminal UL12, UL13, and UL14 RNAs and regulates UL13 expression in vivo. J Virol 2002, 76:8090-8100.

6. Bryant KF, Cox JC, Wang H, Hogle JM, Ellington AD, Coen DM: Binding of herpes simplex virus-1 US11 to specific RNA sequences. Nucleic Acids Res 2005, 33:6090-6100.

7. Diaz JJ, Dodon MD, Schaerer-Uthurralt N, Simonin D, Kindbeiter K, Gazzolo L, Madjar JJ: Post-transcriptional transactivation of human retroviral envelope glycoprotein expression by herpes simplex virus Us11 protein. Nature 1996, 379:273-277

8. Roller RJ, Roizman B: The herpes simplex virus Us 11 open reading frame encodes a sequence-specific RNA-binding protein. Journal of virology 1990, 64:3463-3470.

9. Xing J, Wu F, Pan W, Zheng C: Molecular anatomy of subcellular localization of HSV-1 tegument protein US11 in living cells. Virus research 2010, 153:71-81.

10. Diefenbach RJ, Miranda-Saksena M, Diefenbach E, Holland DJ, Boadle RA, Armati PJ, Cunningham AL: Herpes simplex virus tegument protein US11 interacts with conventional kinesin heavy chain. J Virol 2002, 76:3282-3291

11. Giraud S, Diaz-Latoud C, Hacot S, Textoris J, Bourette RP, Diaz JJ: US11 of herpes simplex virus type 1 interacts with HIPK2 and antagonizes HIPK2-induced cell growth arrest. J Virol 2004, 78:2984-2993.

12. Cassady KA, Gross M: The herpes simplex virus type $1 \mathrm{U}(\mathrm{S}) 11$ protein interacts with protein kinase $\mathrm{R}$ in infected cells and requires a 30-aminoacid sequence adjacent to a kinase substrate domain. J Virol 2002, 76:2029-2035.

13. Peters GA, Khoo D, Mohr I, Sen GC: Inhibition of PACT-mediated activation of PKR by the herpes simplex virus type 1 Us 11 protein. J Virol 2002, 76:11054-11064.

14. Khoo D, Perez C, Mohr I: Characterization of RNA determinants recognized by the arginine- and proline-rich region of Us 11 , a herpes simplex virus type 1-encoded double-stranded RNA binding protein that prevents PKR activation. J Virol 2002, 76:11971-11981.

15. Sanchez R, Mohr I: Inhibition of cellular 2'-5' oligoadenylate synthetase by the herpes simplex virus type 1 Us 11 protein. J Virol 2007, 81:3455-3464.

16. Pan W, Ren X, Guo H, Ding Q, Zheng AC: Expression, purification of herpes simplex virus type 1 UL4 protein, and production and characterization of UL4 polyclonal antibody. J Virol Methods 2010, 163:465-469.

17. Roller RJ, Monk LL, Stuart D, Roizman B: Structure and function in the herpes simplex virus 1 RNA-binding protein $U(s) 11$ : mapping of the domain required for ribosomal and nucleolar association and RNA binding in vitro. Journal of virology 1996, 70:2842-2851.

18. Baines JD, Jacob RJ, Simmerman L, Roizman B: The herpes simplex virus 1 UL11 proteins are associated with cytoplasmic and nuclear membranes and with nuclear bodies of infected cells. Journal of virology 1995, 69:825-833.

19. Wei CJ, Xu L, Kong WP, Shi W, Canis K, Stevens J, Yang ZY, Dell A, Haslam SM, Wilson IA, Nabel GJ: Comparative efficacy of neutralizing antibodies elicited by recombinant hemagglutinin proteins from avian H5N1 influenza virus. J Virol 2008, 82:6200-6208.

20. Khurana S, Verma S, Verma N, Crevar CJ, Carter DM, Manischewitz J, King LR, Ross TM, Golding H: Properly folded bacterially expressed H1N1 hemagglutinin globular head and ectodomain vaccines protect ferrets against H1N1 pandemic influenza virus. PLoS One 2010, 5:e11548.

21. Treanor JJ, Betts RF, Smith GE, Anderson EL, Hackett CS, Wilkinson BE, Belshe RB, Powers DC: Evaluation of a recombinant hemagglutinin expressed in insect cells as an influenza vaccine in young and elderly adults. J Infect Dis 1996, 173:1467-1470.

22. Shen S, Mahadevappa G, Oh HL, Wee BY, Choi YW, Hwang LA, Lim SG, Hong W, Lal SK, Tan YJ: Comparing the antibody responses against recombinant hemagglutinin proteins of avian influenza $A$ ( $\mathrm{H} 5 \mathrm{~N} 1$ ) virus expressed in insect cells and bacteria. J Med Virol 2008, 80:1972-1983.

23. Mayer M, Buchner J: Refolding of inclusion body proteins. Methods Mol Med 2004, 94:239-254.

24. Gustafsson C, Govindarajan S, Minshull J: Codon bias and heterologous protein expression. Trends Biotechnol 2004, 22:346-353.

25. Oneda $H$, Inouye $K$ : Refolding and recovery of recombinant human matrix metalloproteinase 7 (matrilysin) from inclusion bodies expressed by Escherichia coli. J Biochem 1999, 126:905-911.

26. Roller RJ, Roizman B: The herpes simplex virus 1 RNA binding protein US11 is a virion component and associates with ribosomal 605 subunits. Journal of virology 1992, 66:3624-3632.

27. Diaz JJ, Simonin D, Masse T, Deviller P, Kindbeiter K, Denoroy L, Madjar JJ: The herpes simplex virus type 1 US11 gene product is a phosphorylated protein found to be non-specifically associated with both ribosomal subunits. The Journal of general virology 1993, 74(Pt 3):397-406.

28. Tanaka M, Kagawa H, Yamanashi Y, Sata T, Kawaguchi Y: Construction of an excisable bacterial artificial chromosome containing a full-length infectious clone of herpes simplex virus type 1: viruses reconstituted from the clone exhibit wild-type properties in vitro and in vivo. I Virol 2003, 77:1382-1391.

29. Yuen SW, Chui AH, Wilson KJ, Yuan PM: Microanalysis of SDS-PAGE electroblotted proteins. Biotechniques 1989, 7:74-83.

30. Bradford MM: A rapid and sensitive method for the quantitation of microgram quantities of protein utilizing the principle of protein-dye binding. Anal Biochem 1976, 72:248-254.

doi:10.1186/1743-422X-8-490

Cite this article as: Huang et al:: Expression, purification of herpes simplex virus type 1 US11 Protein, and production of US11 polyclonal antibody. Virology Journal 2011 8:490.

\section{Submit your next manuscript to BioMed Central and take full advantage of:}

- Convenient online submission

- Thorough peer review

- No space constraints or color figure charges

- Immediate publication on acceptance

- Inclusion in PubMed, CAS, Scopus and Google Scholar

- Research which is freely available for redistribution

Submit your manuscript at www.biomedcentral.com/submit
Ciomed Central 